$\Xi$

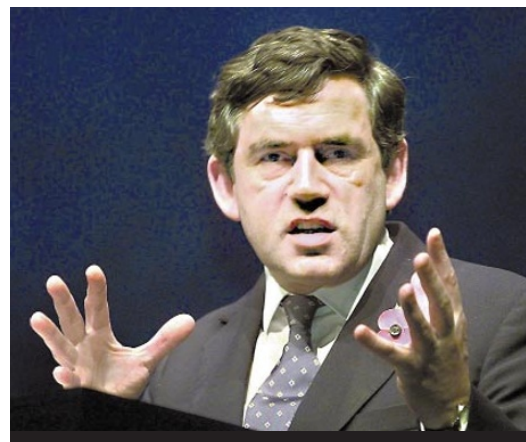

Brown: plans to increase funding, but some fear a cut in the number of studentships.

in many areas, including the biological and physical sciences.

The government has not yet said how much extra money will be available to cover the increases, leading some to fear that student numbers could fall. Earlier this year the life-science community called for a pay increase, even if it meant cutting back on numbers (see Nature 403, 347; 2000). But the Treasury has denied that this is their intention. A spokesperson said the aim was to have more and better research students, and that "this does not mean fewer studentships".

Bob Price, the head of human and corporate resources at the Biotechnology and Biological Sciences Research Council (BBSRC), welcomed the announcement with "open arms" and expects it to raise the quality and quantity of research students.

But earlier this year John Taylor, the director-general of the research councils, decided that stipends did not have to be harmonized, and that individual councils could choose whatever level they thought appropriate. Accordingly, the BBSRC's minimum went up to $\mathfrak{E 7 , 3 8 0}$ and is under review. Price says it could increase beyond the amount announced by the Treasury, but that this would "need a reduction in the number of places".

But although welcoming the money in principle, many scientists are reserving judgement until the small print is revealed later this month particularly as the announcements appeared as a leak to two newspapers of a speech by Gordon Brown, the Chancellor of the Exchequer, and as selective details released by the Treasury.

Indeed, science may not be a net beneficiary. Money could be redistributed from other budgets, as was the case with government departmental spending (see Nature 404, 909; 2000), or clawed back elsewhere. The full results will be known when the government releases details of the Comprehensive spending Review in a few weeks.

\title{
Tangled tale of a lost, stolen and disputed coelacanth
}

Heather McCabe, Paris \& Janet Wright, London Strange stories have long circulated around the coelacanth, the 'living fossil' fish discovered off the coast of South Africa in the 1930s.

The latest are claims by French researchers who say they were the first scientists to find the Indonesian variety, in 1995. But the photograph they sent to Nature to support their claims has been denounced by another researcher as a fake.

Until recently, coelacanths had only been found on the west side of the Indian Ocean. The first recorded Indonesian sample was discovered by a US biologist, Mark Erdmann of the University of California at Berkeley, who published news of his find in Nature (see Nature 395, 335; 1998).

In a recent submission to Nature, the French team - Bernard Séret, Laurent Pouyaud and Georges Serre - say they were unable to register their specimen in 1995 because it failed to reach the museum to which it had been sent. They say Serre photographed the fish at the time, then lost the picture (their only other evidence) while moving house, and only found it again this year.

But Nature staff noticed that the fish in the new photograph appears virtually identical to the one caught by Erdmann. When contacted, Roy Caldwell, a co-author of the 1998 paper, scrutinized the photograph via a picture-editing computer program and said, "I am $100 \%$ certain the image is a fake".

When Erdmann spotted a coelacanth off the northeast coast of Sulawesi in 1998, his find expanded the geographical distribution of the fish by roughly $10,000 \mathrm{~km}$. But Georges Serre, a consultant for what is now the French Institut de Recherche pour le Développe-

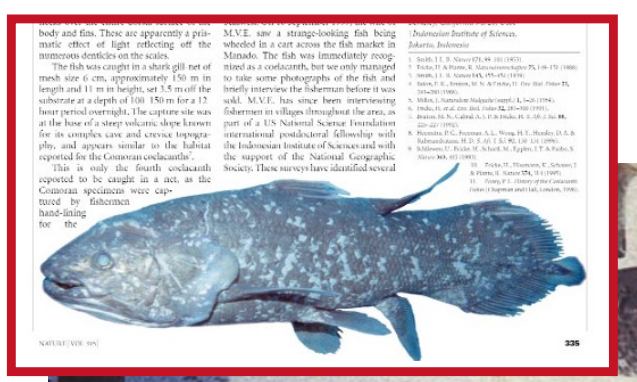

ment (IRD), has long claimed that a $10-\mathrm{kg}$ specimen was caught in 1995 in the Bay of Pangandaran, in Southwest Java.

Serre says he gave the specimen to a fisherman to hand over to the Indonesian fishery service. But the man gave it to a museum, from which it was stolen. Only recently, according to Serre, did Pouyaud, an IRD geneticist in Jakarta, track down the coelacanth to a private collection, whose owner refuses access to the fish.

The French team's finding, if confirmed, would further extend the distribution of this elusive creature, as it was caught more than 2,000 $\mathrm{km}$ from the spot where Erdmann found his 1998 specimen, suggesting a large distribution in the Indo-West Pacific region.

The whole issue is already shrouded in controversy. After analysing the specimen that Erdmann had given to the Indonesian authorities, Pouyaud and his colleagues at the Indonesian Institute of Science named it as a distinct species, Latimeria menadoensis - to the chagrin of Erdmann, who had been analysing tissue samples independently.

Caldwell says that coelacanths have highly individual spot patterns; the pattern in the two photographs is virtually identical. The bulky fish in the 1998 photo was swimming in the sea, yet is seen in the identical position, in the new photo, while lying on a slab. Shadows and other details seen when the image is magnified add to Caldwell's impression that the new photograph has been manipulated.

Serre still claims that the photograph is authentic, though he now says it was taken by a friend who later died and whose widow gave it to Serre before moving abroad.

Séret, who is an ichthyologist at the Muséum National d'Histoire Naturelle de Paris, admits that the two photographs do appear to show the same fish. "This is very embarrassing," he says. 